\title{
A new delegation design for EU governance: how preference cohesiveness of multiple principals shapes the European Commission's discretion in trade negotiations
}

\section{Eugenia C. Heldt ${ }^{1}$}

Accepted: 24 May 2021 / Published online: 24 June 2021

(c) The Author(s) 2021

\begin{abstract}
The Lisbon Treaty enhanced the role of the European Parliament in free trade agreements. This article offers a comprehensive theoretical and empirical account of this new delegation design in EU trade governance. Specifically, it addresses the question how the preference cohesiveness of multiple principals-the Council of Ministers as a de jure principal and the Parliament as a de facto principal-shapes the Commission's discretion in negotiating trade agreements. Exploring these two conjectures through a combination of primary materials and interviews, this contribution posits that those configurations of low degree of cohesiveness within the Council and high cohesiveness within the Parliament or high cohesiveness of the Council and low cohesiveness within the Parliament increase Commission discretion. A configuration of low cohesiveness within and between multiple principals, by contrast, is more likely to lead to paralysis of the negotiation process.
\end{abstract}

Keywords Trade negotiations · European Commission · European Parliament · Multiple principals $\cdot$ Principal-agent $\cdot$ Discretion

\section{Introduction}

The Treaty of Lisbon gave the European Parliament (EP) considerable powers over the EU's trade policy, including the right to veto international trade agreements. The European Commission (henceforth, the Commission) negotiates on behalf of Member States represented in the Council of Ministers, which authorizes the opening of negotiations, and the EP gives its consent after the conclusion of agreements. Whilst the Council can be considered a formal or de jure principal, the EP is an informal or

Eugenia C. Heldt

eugenia.heldt@hfp.tum.de

1 TUM School of Governance, Technical University of Munich, Richard-Wagner-Straße 1, 80333 Munich, Germany 
de facto principal. This new delegation design with multiple principals ${ }^{1}$ (the Council and the EP) enhances the involvement of the Parliament in the formulation, negotiation, and ratification of trade agreements. Against this backdrop, we examine the extent to which preference cohesiveness between the Council and the EP, as well as within the Council and the EP shapes the Commission's discretion in trade negotiations. Understanding this new interinstitutional constellation is central to the theory and practice of European trade governance. Once we know how European institutions interact under the new delegation design, we can address more fundamental questions, including whether this new interinstitutional constellation affects the EU's prospect for successful negotiations with third parties.

Whilst an early wave of research on the EU's institutional framework and trade negotiations investigated the relationship between the Commission and the Council of Ministers in trade negotiations (Billiet 2006; Dür and De Bièvre 2007; Dür and Zimmermann 2007; Meunier and Nicolaidis 1999; Woll 2006; Young 2002), post-Lisbon studies examine the institutional interaction of the Commission, Council, and EP (De Ville and Siles-Brügge 2016; Khorana and García 2018; Rosén 2017; Young 2017). More specifically, the delegation literature (Pollack 1997, 2003; Tallberg 2000; Thatcher and Stone Sweet 2002; Gilardi 2008; Dür and Elsig 2011; Conceição-Heldt 2010, 2011), zooms in on how principal cohesiveness shapes agent discretion (Niemann and Huigens 2011; Nicolaidis 1999; Delreux and Adriaensen 2017; Heldt 2017a), determines EU external effectiveness in global governance (Elsig 2013; Macaj and Nicolaïdis 2014; Meunier 2000, 2014; Moschella and Quaglia 2015; Thomas 2012; Niemann and Bretherton 2013; Conceição-Heldt 2014; Conceição-Heldt and Meunier 2014; Heldt 2020), and the extent to which the EP has been empowered by the Treaty of Lisbon (Rosén 2015; Young 2012; Jančić 2016; Larsén 2020; Servent 2014).

This paper contributes to the literature by investigating whether the configuration of preference cohesiveness between and within multiple principals (the Council and the EP) shapes the agent's (Commission's) range of discretion in trade negotiations. To this end, we engage with earlier writings on negotiation theory that directly speak to the agent's discretion as a function of the principal's configuration in trade negotiations (Nicolaidis 1999; Kaufman 1999; Bazerman 1999; Mnookin and Cohen 1999). This goes back to the tradition of bringing negotiation theory together with delegation literature and EU trade negotiations studies (Dür and Zimmermann 2007; Heldt 2017b). Preference cohesiveness is defined as the extent to which multiple principals' preferences align or conflict internally. To the extent that multiple principals' preferences align, the agent's discretion in trade negotiations can range from acting as a passive messenger defending the united position of principals (low discretion) to assuming the role of a party in international trade negotiations enjoying strong discretionary powers-where

\footnotetext{
1 The term multiple principals refers to a delegation constellation in which agents have to report on their actions to more than one collective principal. When agents have single contracts with a principal, but the principal is composed of more than one actor, as is the case in the Council of Ministers, we call this a delegation relationship with a collective principal (see also Nielson and Tierney 2003).
} 
the preferences of multiple principals are in conflict. When we speak of unity with respect to multiple principals, we mean unity within collective principals and between multiple principals prior, during, and after trade negotiations (see also Nicolaidis 1999: 91). Whilst unity within collective principals means unity among Member States in the Council and among party fractions in the EP, unity between multiple principals refers to a united position between the Council and the EP. Furthermore, by the agent's range of discretion we mean the leeway conferred on the agent by multiple principals to accomplish a delegation mandatee.g. the successful conclusion of a trade agreement (see also Heldt 2017a). We thus conceive this new interinstitutional constellation under the Lisbon Treaty as a complex delegation relationship, in which the Commission negotiates trade agreements on behalf of multiple principals-namely the Council representing Member State governments and (informally) on behalf of the EP representing the European electorate.

Drawing on delegation literature, we posit that the lower cohesiveness is between multiple principals - and thus the greater preference heterogeneity is within the Council and the EP, as well as between the Council and the EP-the more discretion will be granted to the agent. The existence of multiple principals enhances the potential for agents to orchestrate and, in some cases, play a more proactive role in shaping the outcome of negotiations. The paper explores four different possible configurations with multiple principals: high cohesiveness between and within the Council and the EP; low cohesiveness within the Council and high cohesiveness within the EP; high cohesiveness within the Council and low cohesiveness within the EP; and low cohesiveness within Council and EP. A situation is marked by low cohesiveness when the preferences of multiple principals conflict internally, increasing the discretion of the agent. The Commission can point to recalcitrant principals in order to obtain more concessions from third parties (Putnam 1988; Schelling 1960). Negotiation theory is very much about the tension between reducing the size of the zone of possible agreement (ZOPA) externally whilst allowing for value to be claimed from tied hands. By contrast, high cohesiveness between multiple principals means that these principals take a united position (homogeneity of preferences), speaking with a single voice before, during, and after negotiations. This configuration, however, can decrease EU bargaining leverage and lead to less discretion for the agent.

To explore the dynamics of this new interinstitutional constellation, this contribution first theorizes the nexus between multiple-principal cohesiveness and agent discretion in trade negotiations. Second, it briefly presents the research design and data sources, followed by a third section unpacking the preferences of the Council and of the EP on trade policy. The fourth section illustrates the argument on the basis of four case studies on trade agreements: EU-Singapore, which stands for a configuration of high cohesiveness within the Council and the EP and low discretion for the Commission; EU-South Korea, a configuration of low cohesiveness within the Council and high EP cohesiveness with high discretion for the Commission; EU-Canada characterized by high cohesiveness within the Council, low cohesiveness within the EP and with high discretion for the Commission; and EU-USA with low cohesiveness within Council and EP and high discretion for the Commission. 
Finally, we summarize the findings and outline their implications for EU trade politics and complex delegation relationships.

\section{Nexus between multiple-principal cohesiveness and an agent's discretion on trade issues}

This section theorizes the nexus between multiple-principal cohesiveness and how it shapes agent discretion. Before turning to our argument, we elaborate on the following aspects: Member States' rationale for delegating power on external trade issues to the Commission; how the extent of agency discretion might lead to agency losses; and how this delegation relationship leads to a new interinstitutional constellation.

The rationale behind delegating authority to the Commission was first and foremost technical: given that the EU is a customs union, there was no alternative under GATT to speaking with one voice (see also Meunier 2000). This means in practice that Member States, represented in the Council, empowered the Commission to act on their behalf in negotiating trade agreements. Over past decades, the delegation design has changed. Whilst the Treaty of Amsterdam in 1999 introduced an enabling clause to allow for the future expansion of EU competence to agreements on services and intellectual property rights, under the Treaty of Nice in 2003 the EU gained exclusive competence for trade in services. Finally, the Treaty of Lisbon consecrated the extension of exclusive competence for the EU in foreign and direct investment (FDI), transport services, as well as development provisions. In new-generation and bilateral investment treaties, Member States retained exclusive competence only in portfolio investment and investor-to-state dispute settlement matters (Gstöhl and De Bièvre 2017). The Treaty of Lisbon also changed delegation design, as the EP now has joint powers with the Council on trade agreements at the ratification stage. Following the recent interinstitutional arrangement and agreements between the EP and the Commission as well as the Commission's transparency initiative, the Commission provides extensive information to the EP on the state of negotiations. Whilst the Council still has exclusive competence to grant negotiation mandates to the Commission, in the course of negotiations the Commission reports back to the Council and to the EP to avoid involuntary defection at the ratification stage (Putnam 1988; Sebenius 1991). Accordingly, the Commission is fully aware that providing insufficient information during the negotiations, for example by not giving access to negotiating texts, could have negative consequences at the ratification stage. Moreover, the EP's routine of adopting a resolution as a surrogate mandate at the start of the negotiations automatically makes it a de facto principal. This resolution can be considered an informal act of delegation from a principal-agent perspective, as the EP "briefs" the Commission on the issues that have to be taken into account when negotiating a trade agreement in order to garner support at the ratification stage. This new complex delegation relationship raises the question of how preference cohesiveness between and within multiple principals shapes agent discretion in trade negotiations.

Whilst the delegation of power allows principals to accomplish desired ends more efficiently, it can also lead to agency losses or even agency slack, depending 
on the range of discretion principals confer on their agents (Heldt 2017b). The negotiation of free trade agreements (FTAs) is hence a complex delegation relationship in which the Commission acts under close scrutiny from multiple principals. This delegation relationship can be tense, particularly if agents seek to hide information from their principals, who might react by strengthening oversight mechanisms. Consequently, the range of discretion conferred on agents in the conduct of negotiations is of crucial importance in understanding delegation relationships. Discretion gives agents a certain leeway in fulfilling their mandates, ideally with less interference from multiple principals (see also Hawkins et al. 2006; Conceição-Heldt 2013). In the case of trade negotiations, the Council (directly) and the EP (indirectly) exercise extensive control over the Commission's actions before, during, and after negotiations. The negotiating mandate broadly stipulates general negotiation guidelines, specifies the preferences of Member States within the Council relative to the successful conclusion of trade negotiations, and sets out priorities of the collective principal regarding the degree of concessions the agent is allowed to make on various issues. Nonetheless, EU negotiating mandates are sufficiently vague to leave the Commission considerable discretion with respect to specific negotiating tactics in pursuit of a trade agreement that can then be ratified by multiple principals.

By discretion, we mean the leeway multiple principals give their agents within a delegation mandate. We consider discretion to be high when the level of multiple principals' interference in an agent's actions before, during, and after negotiations is minimal. Low discretion, by contrast, characterizes a situation in which the level of multiple-principal interference in an agent's actions before, during, and after negotiations is extensive. This can be the case when principals interfere directly in negotiations, for instance, by calling the agent back on the grounds that it has surpassed the red lines of the negotiating mandate. We posit that agency discretion should be greater under a configuration of low cohesiveness than under a configuration of high cohesiveness of multiple principals. Under a configuration of high multiple-principal cohesiveness with internally aligned preferences, agents will have less discretion (see also Nicolaidis 1999). By contrast, in configurations where the cohesiveness within the Council is low, high within the EP and vice versa and their preferences conflict internally, the agent is likely to be granted greater discretion. These different configurations of preference cohesiveness also have different effects on negotiation outcomes. First, when multiple principals are united (highly cohesive), agent discretion is low but negotiations are more likely to end successfully. In a situation of high cohesiveness within and between multiple principals, the agent is able to speak with a single voice when negotiating externally. Second, when multiple principals are less cohesive (meaning that they are divided and have heterogeneous preferences), this can give agents more flexibility and discretion during negotiations. The agent might even use a divide-and-conquer strategy by playing multiple principals or members of the collective principal off against each other (Cutcher-Gerschenfeld and Watkins 1999). However, this configuration can also come with the risk of deadlocked negotiations due to disunity within collective principals (Council and EP) and between multiple principals. In the end, it can lead to negotiation processes being paralysed or to involuntary defection at the ratification stage, as division within and between 
multiple principals can result in extensive disagreement during negotiations on the scope of concessions.

Agents are exposed to various pressures when acting on behalf of multiple principals. This can lead to situations in which agents negotiate beyond their mandate, leading to more discretion vis-à-vis their principals (Delreux and Adriaensen 2017). Contrary to the conventional wisdom that agents benefit from indefinite information asymmetry, we expect information asymmetry and hiding information at the negotiation stage to come at the price of involuntary defection or failed ratification (Putnam 1988: 438). In other words, very high levels of information asymmetry may increase the discretion of the agent at the negotiation stage but can increase the probability of rejection by the Council or EP at the ratification stage. By contrast, when information is distributed symmetrically between agent and principals, it decreases the discretion of the first but reduces the risk of involuntary defection (Coremans and Kerremans 2017). Moreover, it can also entail consequences in iterative delegation relationships. The strategic advantage in terms of discretion may very easily be exceeded by the costs of unvoluntary defection. At the ratification stage, involuntary defection can occur in situations of either high or low agency discretion. Whilst in situations of high discretion, if the agent misperceives multiple principals' preferences or their ZOPAs, ratification might fail, in situations of low discretion depending on the extent to which the agent provides extensive information on the state of negotiations, conflictual situations between the agent and multiple principals might arise during or after negotiations. To the best of our knowledge, this piece constitutes one of the first theoretical and empirical attempts to build on the seminal study by Nicolaidis (1999), in which she argues that optimal mandates in two-level games negotiations involve balancing external efficiency with internal equity. She was one of the first to offer a typology of principal-agent interest configurations specifically examining the degree of interest alignment between agent and principals as well as the degree of interest alignment among principals. We add to this literature by examining how the degree of cohesiveness within and between multiple principals shapes the degree of agent discretion. This enables us to zoom in on the relationship between the Commission, the Council, and the EP, providing a more detailed account of the interinstitutional dynamics between them. In so doing, this piece focuses on two stages of negotiations through agents during and after trade negotiations. Thereby, we suggest that one of the main concerns of principals is how much discretion to give agents going into negotiations (see also Nicolaidis 1999; Kaufman 1999).

\section{Research design and data sources}

Since the entry into force of the Lisbon Treaty, the EU has successfully negotiated over ten bilateral trade agreements with South Korea (2010), Columbia and Peru (2012), Central America (Costa Rica, El Salvador, Guatemala, Honduras, Nicaragua, and Panama; 2012), Iraq (2012), Canada (2013), Singapore (2014), the Ukraine (2015), Mexico (2018), Vietnam (2019), Japan (2019), and Mercosur (2019). At the same time, the EU is negotiating over 20 bilateral trade agreements, including those 
Table 1 Configuration of preference cohesiveness of multiple principals and its impact on agent's discretion

\begin{tabular}{|c|c|c|c|c|}
\hline & \multicolumn{2}{|c|}{$\begin{array}{l}\text { Preference cohesiveness of } \\
\text { multiple principals }\end{array}$} & \multirow[t]{2}{*}{ Agent's discretion } & \multirow[t]{2}{*}{ Trade agreement } \\
\hline & Council & EP & & \\
\hline Configuration 1 & High & High & Low & Singapore \\
\hline Configuration 2 & Low & High & High & South Korea \\
\hline Configuration 3 & High & Low & High & Canada \\
\hline Configuration 4 & Low & Low & High & US \\
\hline
\end{tabular}

with Australia, and New Zealand. To illustrate our argument, we have selected case studies from these bilateral trade agreements that highlight four possible configurations of cohesiveness between multiple principals. Configuration 1 refers to a situation in which both the Council and the EP were highly cohesive, as was the case in the FTA negotiations with Singapore. Configuration 2 illustrates a situation of a less cohesive Council but a highly cohesive EP, as demonstrated in the negotiations with South Korea. Configuration 3 analyses a highly cohesive Council matched with a less cohesive EP in the EU-Canada negotiations. Finally, configuration 4 illustrates a situation where both the Council and the EP demonstrate low cohesiveness, as in the failed TTIP negotiations (Table 1). Whilst these negotiations failed, we have included the first three years of the negotiations from July 2013 to December 2015. This is necessary to allow us to include a configuration of multiple principals with low cohesiveness. Even though, in the specific TTIP case, the change in President Trump's stance towards trade was the key reason why negotiations failed, including the TTIP allows us to discuss a configuration of multiple principals with low cohesiveness-low unity within collective principals as well as between multiple principals.

This piece contributes to the literature in four ways. First, we analyse how new interinstitutional dynamics with multiple principals shape EU trade governance. Second, we unpack Member State and EP preferences on trade policy. Third, we explore four different possible configurations of preference cohesiveness between multiple principals and demonstrate how they shape the agent's range of discretion. Fourth, this piece is based on primary sources from the Commission's Directorate General (DG) Trade, press releases, as well as statements from the Trade Policy Committee (TPC) at the Council, the International Trade Committee (INTA) at the EP, plenary debates, and on semi-structured interviews conducted by the author with representatives from the DG Trade, the TPC, and the INTA. ${ }^{2}$

\footnotetext{
${ }^{2}$ Interviews with officials from the Commission, EP and the Council were conducted in Brussels between January 11 and 15, 2016. I am particularly grateful to the following European officials for their availability and willingness to share their knowledge with me: John Clarke, Luca De Carli, Ignacio Garcia-Bercero, Lutz Güllner, Bostja Krasovec, Alda Silveira Reis, and Ruta Zarnauskaite. All interviews agreed to talk with me on anonymous basis. None of the opinions expressed by European officials are therefore attributed to a particular person. As a result, all interviews are cited in chronological number.
} 


\section{Multiple principals' preferences on trade policy}

Preference cohesiveness within collective principals can vary and shape the degree of an agent's discretion. Preference cohesiveness means the extent to which multiple principals have heterogeneous (conflicting) or homogeneous (internally aligned) preferences on trade agreements. Multiple-principal unity means unity both within collective principals and between multiple principals at the different stages of negotiation (Nicolaidis 1999: 91). We accordingly distinguish between unity within collective principals and unity between multiple principals. Unity within collective principals refers to a united position among Member States in the Council and the among party fractions within the EP. By contrast, unity between multiple principals defines a situation of unity between the Council and the EP.

When it comes to trade liberalization, the preferences of the 27 member states vary from net importers vs. net exporters to protectionist vs. free traders, whereby the main divide is between those with liberal and protectionist trade preferences. By liberal preferences, we mean that a state favours more trade liberalization in a given economic sector. A protectionist trade preference means that a country wants to keep the status quo by maintaining a high level of protection for a certain economic sector. Countries can have protectionist positions in one economic sector and liberal positions in another. Member States often have to balance the gains and losses of different sectors during negotiations. Export-oriented countries such as Germany and the Netherlands have generally taken a liberal position on industrial, financial, and services issues. Yet, when it comes to agricultural issues, Germany aligns itself with protectionist countries such as France, the Mediterranean countries, Poland, Cyprus, and Hungary. The Scandinavian countries are liberal in industrial and service sectors, but protectionist when it comes to agriculture-Denmark and Finland-and to labour standards-Sweden (see, e.g. Van den Hoven 2002; Dür 2008). To be internally cohesive, the preferences of Member States have to be aligned. Moreover, intra-Member State cohesiveness is nested within Council cohesiveness as a whole and is itself nested in EU cohesiveness.

Similarly, the EP's trade policy preferences will be assessed by focusing on the degree of cohesiveness among different political groups on trade issues. Political group cohesiveness is nested within EP cohesiveness as a whole and is itself nested in EU cohesiveness. Van den Putte et al. (2015) show that political group cohesiveness is stronger on international trade issues than on all other issues. They looked at the votes for specific trade agreements and found that there is a left-right division. Leftist parties, such as the European United Left and the Greens, voted against trade agreements proposed by the Commission as well as against the amendments made by the EP. Christian democratic and liberal party groups, such as the European People's Party (EPP), the Alliance of Liberals and Democrats for Europe (ALDE), and the European Conservative and Reform Party (ECR), mostly favour trade agreements and thus more free trade. In general, social democratic parties, assembled in the Progressive Alliance of Socialists and 
Democrats in the EP, aligned with centre-right and Christian democrats, favour trade agreements under the condition that market regulations and labour standards are included. By contrast, extreme-right and populist, anti-EU parties, such as the Europe of Freedom and Democracy group, have low cohesiveness on international trade agreements and hitherto have sometimes voted in favour and sometimes against trade agreements. Thus, the EP's preference on trade policy goes back to the ideological position of party groups. MEPs oppose free trade because this is part of the programme of the group they represent in the EP (interviews with Commission's official\#13 and Council's official \#11). Even though the EP itself considers that its preferences on trade agreements are broader than those of the Council, as it is more concerned with normative issues, when it comes to the negotiation and ratification of trade agreements, narrow sectoral interests and party programme concerns predominate (interviews with Commission's official\#12 and EP official's \#11). The next section analyses the extent to which different configurations of preference cohesiveness among multiple principals shape agent discretion in negotiating FTAs.

\section{Configuration 1 EU-Singapore FTA: high cohesiveness within the Council and the EP}

The EU-Singapore FTA, negotiated between May 2007 and October 2014, was signed in October 2018. The EP gave its consent to the FTA on 13 February 2019 and Member States endorsed it on 8 November 2019. It entered into force on 21 November 2019 (European Commission 2020). The EU-Singapore agreement corresponds to a configuration in which the Council and the EP were both highly cohesive, resulting in low discretion for the Commission.

There was broad consensus within Council and EP that the agreement would create benefits for everyone. Since trade relations between the EU and Singapore, involving some 8,000 European businesses, are intense, the agreement gave EU agricultural, agribusiness, automobile, and services sectors access to a dynamic market. Member States, EP, and Commission unanimously agreed that Singapore was a gateway for European business and could catalyse growth for EU exporters. This was particularly important, as negotiation and conclusion of the FTA took place during the euro crisis. Singapore accepted major EU demands, including the recognition of EU standards for manufactured cars and agricultural products. The latter included protecting geographical designations of origin. Taking the preferences of the EP into account, the agreement also included a chapter on trade and sustainable development with the aim of stimulating trade and investment in environmental technologies and renewable energies. At the same time, tariff rates on environmental goods were to be abolished (Agence Europe 2012). These issues were particularly relevant for green and leftist groups within the EP. By taking these preferences into account, it was more likely that a majority of MEPs from these parties would vote in favour of the agreement (interviews with Commission's official\#13, and Council's official\#12). Following the opinion of the European Court of Justice on whether this FTA, including investment issues, fell within the EU's exclusive or shared 
competences, the result of the negotiations was adjusted to create two standalone agreements: a FTA and an investment protection agreement. Because the Lisbon Treaty did not specify whether the transfer of competences on FDI included only investment liberalization (market access) or also investment protection, and whether it was restricted to long-term FDI or also included portfolio investment, Opinion 2/15 of the European Court of Justice ruled that investment protection falls within the common commercial policy. Portfolio investment and investor-to-state dispute settlement are now shared competences between Member States and the EU (Gstöhl and De Bièvre 2017: 41).

On 13 February 2019, the EP ratified the EU-Singapore FTA by 425 votes to 186 and with 41 abstentions (European Commission 2019). Altogether, the EU-Singapore FTA provided major gains for the EU services sector, notably insurance, banking, and financial services. As Singapore does not have an agricultural sector or an automobile industry, the EU did not have to defend key sectors. As a result, Member States with a more protectionist position on these two issues could easily accept the agreement, and gains for all European economic sectors should be high (interviews with Council's official\#12 and Commission's official\#14). During plenary discussion in the EP, rapporteur David Martin stressed that this agreement was a win-win situation for both European companies, protecting EU products and eliminating all tariffs. Even the investment agreement had a number of safeguards guaranteeing the independence of judges and a number of safeguards in the investor-state dispute settlement mechanism (ISDS) (European Parliament 2019).

Altogether, the preferences of Member States and of MEPs were internally aligned, with a vast majority in both Council and Parliament supporting the trade agreement, which included a section on sustainable development and environmental standards. This configuration of high cohesiveness between and within multiple principals correlated with low agent discretion and extensive reporting to the respective trade committees. This case study shows that not only cohesiveness within the EP and the Council mattered. Equally important was the convergence of preferences between them enabling the successful conclusion of the agreement.

\section{Configuration 2 EU-South Korea FTA: low cohesiveness within the Council and high cohesiveness of the EP}

Negotiations on the FTA with South Korea began in May 2007. The agreement was signed in April 2011, provisionally applied in July 2011, and entered into force in December 2015 (European Commission 2020). This configuration corresponds to a low cohesive Council and a highly cohesive EP.

The main issues at stake for the EU were to obtain better access to the South Korean market for its automobile, pharmaceutical, cosmetic, chemical industries, and services sector. The South Korean government, in turn, asked for better market access for its automobile, electronic, and textile sectors (Agence Europe 2007). From the very beginning, the European economic sectors that would lose most from a change of status quo, including the automobile and textiles sectors, mobilized to demand protective measures. For example, they called for a system 
of import surveillance and opposed the use of a South Korean duty drawback safeguard mechanism, that is to say, duties paid on parts and components used to produce a final product that are refunded when the final product is exported. By contrast, the European communications and financial and banking service sectors would gain most from an FTA (Directorate General for External Policies 2009). This was reflected in the division within the Council between countries with a protectionist trade preference for their automobile and textile sectors and a liberal trade preference for the services sectors. Whereas Member States with a protectionist position regarding automobiles and textiles-including Germany, the Czech Republic, France, Hungary, Italy, Poland, Portugal, Slovakia, and Spain-opposed liberalizing trade without protectionist measures for these sectors, countries with a liberal trade preference towards services (such as the UK and Sweden) asked for the swift conclusion of the FTA (Agence Europe 2009b; interviews with Commission's official\#12 and Council's official\#12).

Aware of the low degree of cohesiveness within the Council, the Commission reported superficially to the TPC and INTA on the state of negotiations to increase its discretion. When, in July 2009, several Member States asked the Commission to specify what effects a South Korean duty drawback clause would have on the European automobile sector, Commission officials could not provide a substantive response and even refused to forward the full 1,000 pages of the FTA throughout the course of negotiations (Agence Europe 2009a). Negotiations moved forward only when Germany switched its position and decided to support the whole package. The Italian government, by contrast, demanded a special regional safeguard clause that would allow Italy to increase customs duties in the event of a massive influx of South Korean cars into its market and asked for a longer implementation period of one year before accepting the agreement (Agence Europe 2010b; interview with Commission's official\#12).

During negotiations, the EP signalled to the Commission that it would ratify the agreement only if a strong safeguard clause allowing the EU to suspend further reductions in customs duties and an Advisory Trade Committee were included in the FTA (Committee on International Trade: European Parliament 2010; Agence Europe 2010a).

The high cohesiveness within the EP during and after negotiations translated into an absolute majority of over 80 per cent across left, social democratic, and centre-leaning Christian democratic and liberal group supporting the EU-South Korea FTA - with 465 votes in favour, 128 against, and 19 abstentions (European Parliament 2011b). In the plenary session, the rapporteur on this FTA, Robert Sturdy, stated that: "With the safeguard clause built in, this deal is very good news for European industry. We have opened our markets to cheaper products that will benefit consumers and Korea has opened its markets for our exporters, who will benefit from significant extra demand" (European Parliament 2011b).

Even though during the negotiation process the Commission had to integrate demands from Council and EP that were not included in the original mandate, a low degree of cohesiveness within the Council and a highly cohesive EP gave the Commission a high range of discretion throughout the negotiation process. 


\section{Configuration 3 EU-Canada FTA: high cohesiveness within the Council and low cohesiveness within the EP}

Negotiations with Canada on the EU-Canada FTA began in June 2006 and were concluded in September 2014. The EU-Canada agreement has not yet entered into force because it still has to be ratified by national parliaments in EU countries. It has applied only provisionally since September 2017 (European Commission 2020). This configuration corresponds to a highly cohesive Council and a low cohesive EP at the ratification stage.

Member States were in a highly cohesive position in the sense that they were united (homogeneity of preferences), speaking with a single voice during and after the negotiation process. On the most controversial issues, such as agriculture and services, the EU and Canada agreed on partial liberalization. This led to the exclusion of 145 products with geographical indications, public services, audio-visual, and transport services from the agreement (Directorate General for External Policies Policy Department 2014). This allowed the Commission to incorporate the position of Member States with a more protectionist position on agriculture and services, such as France, Spain, and Italy, into the negotiations.

By contrast, cohesiveness within the EP on the EU-Canada FTA was low. There were divisions across different parliamentary groups on the inclusion of an ISDS, with some parliamentary groups accusing the Commission of having failed to strike a balance in economic liberalization by protecting investors and consumers and safeguarding governments' regulatory capacity. The Progressive Alliance of Socialists and Democrats (S\&D), which from 2014 to 2019 held 191 seats and was thus the second largest group in the EP, threatened in March 2015 to reject the final agreement if the investment clause was not substantially revised. ${ }^{3}$ This group also had the support of all leftist and green parties-notably the Confederal Group of the European United Left-Nordic Green Left (52 seats), the Greens/European Free Alliance (50 seats), and the Europe of Freedom and Direct Democracy group (48 seats). Together, they had a majority of seats: 341 of 751. If one includes "non-attached" MEPs, a 52-seat right-wing bloc also opposed to the EU-Canada FTA, there was no majority in sight for to ratify the agreement. Support came from the Christian democratic European People's Party with 221 seats, the liberal Alliance of Liberals and Democrats for Europe with 67, and the conservative European Conservatives and Reformists with 70 (European Parliament 2021; interviews with Commission's officials\#11, \#14 and EP's official\#13). To avoid involuntary defection at the ratification stage, the Commission took the demands of the EP on ISDS into account (interview with Commission's officials \#12 and \#15).

During negotiations, the PPE Group asked for an adjustment of the Commission's negotiating position with regard to investment protection in the context of ISDS and more protection of intellectual property rights for European geographical

\footnotetext{
3 This issue became politically salient because the Commission's mandate to negotiate with the USA on TTIP was identical to the EU-Canada's negotiating mandate. This meant that, by accepting ICSD in the EU-Canada agreement, the EU would automatically accept such a clause on TTIP as well.
} 
indications. The $\mathrm{S} \& \mathrm{D}$ group underlined the importance of improving regulatory standards for genetically modified organism. At the same time, the chair of the Parliamentary Committee on International Trade, Vital Moreira, asked the Commission to fulfil the duty of providing information to the EP (European Parliament 2011a). These demands from the de facto EP as a collective principal decreased the Commission's discretion during negotiations, as it had to renegotiate these issues with Canada. This has, for example, led to the inclusion of a long list of geographical indications with more than 145 products to the FTA (European Parliament 2014).

With a highly cohesive Council and a low cohesive EP, the Commission's discretion was high during negotiations. At the ratification stage, however, the Commission's discretion was challenged by the EP and by national and regional parliaments. This explains why, after conclusion of the agreement in 2014 and consent from Council and EP in October 2016, this trade agreement still needs to be ratified by national parliaments and even by some regional parliaments.

\section{Configuration 4 EU-US FTA: low cohesiveness within and between Council and EP}

TTIP negotiations took place from July 2013 to October 2016 and came to a standstill after the election of Donald Trump. This case corresponds to a configuration of a low cohesiveness between the Council and the EP as well as within the Council and the EP.

The highly complex TTIP negotiations involved 150 officials divided into 24 negotiating groups addressing market access, regulatory issues and non-tariff barriers, trade-related rules, and investment protection. Whereas the Council's mandate on market access stated only that the elimination of all tariff rates should exclude most sensitive products (Council of the European Union 2014), the EP reacted by asking for all sensitive agricultural and industrial products to be excluded from tariff reduction (European Parliament 2015b). On investment protection, which has become one of the most controversial issues so far, multiple principals were equally divided. Whilst the Council's mandate foresaw the establishment of an ISDS (Council of the European Union 2014), the EP demanded that the ISDS system be replaced by a new system subject to democratic principles, transparency, and an independent appellate body (European Parliament 2015b). In conjunction with opposition from some major Member States-notably Germany and France-and civil society groups, this position politicized negotiations and decreased the Commission's discretion.

At the time of negotiations, Germany was governed by a grand coalition of Christian and Social Democrats. In keeping with the position of his Social Democratic Party (SPD) and the S\&D group at the EP, the German Minister of Economic Affairs, Sigmar Gabriel, linked German support for TTIP with withdrawal of the arbitration clause (EurActiv 2014). Moreover, Germany and France openly contested the authority of the Commission because they considered that it was conceding too much without obtaining any concessions from the USA. France even made 
its support for the continuation of negotiations conditional on protection for geographical indications and the establishment of an appellate body (EurActiv 2014).

In February 2015, there was even a vote in the EP on continuing negotiations. It failed, however, due to the number of amendments and requests for separate votes. A second attempt took place on 8 July 2015. This time, 436 of 709 MEPs voted in favour of continuing negotiations, 241 against, whilst 32 abstained. Whilst Christian Democrats and Liberals voted in favour, rightist, leftist, and green parties voted against. Moreover, there was low intra-group cohesion in the S\&D. This translated into 116 votes for and 56 against continuing TTIP negotiations (European Parliament 2015a; Votewatch 2015). To obtain the support of the S\&D, the Commission proposed a new Investment Court System with publicly appointed judges (European Commission 2015). S\&D support was particularly important to obtain broader support from Germany - a country that would have benefited most from free trade but whose population was the least convinced about the benefits of a TTIP.

Under a configuration of low cohesiveness within and between multiple principals, the Commission's discretion during TTIP negotiations was high. But it can come at the price of involuntary defection at the ratification stage. The EU's negotiating text had to be updated on several occasions due to opposition from major Member States and MEPs on the ISDS. In this specific case, however, not only preference heterogeneity of multiple principals explains why negotiations failed. Equally important was the contestation of TTIP in some countries, such as Germany and France, and the election of the new US president Trump, who opposed the continuation of negotiations (see Heldt 2020).

\section{Conclusion}

This contribution has explored a neglected issue, namely the impact of the cohesiveness of preferences on the discretion with which the Commission negotiates trade agreements on behalf of multiple principals - the Council as a de jure principal and the Parliament as a de facto principal. Specifically, it examines the impact of the new powers of the Parliament on trade negotiations. It systematically analyses the impact of preference heterogeneity within the Council and the EP, as well as between the Council and the EP and its impact on the discretion granted to the Commission. It compares four case studies: the EU-Singapore FTA; the FTA with South Korea; the EU-Canada FTA; and the failed EU-US TTIP.

The findings of this study suggest that preference cohesiveness of multiple principals has two different effects on the Commission's degree of discretion in the negotiation of trade agreements and thus on the prospects for successful negotiations with third parties. First, when multiple principals are united and speak with a single voice, as in the EU-Singapore negotiations, the agent's discretion is low and negotiations are more likely to end successfully. Second, in a configuration of divided multiple principals, the discretion of the agent can be high at the negotiation stage but with the risk of involuntary defection at the ratification stage, where agents overreach their mandate or do not sufficiently inform multiple principals on the extent of concessions. This configuration can make it more difficult to reach an agreement. 
This study also opens avenues for further research. First, the politicization of EU trade governance is a new phenomenon. How will the contestation of EU trade governance shape the Commission's ability to effectively negotiate trade agreements? Second, we are aware that discretion of the agent may, of course, be conditioned by factors other than the configuration of the preferences of multiple principals. Future studies could, for example, examine further causal mechanisms-including the bargaining power of the parties involved, the complexity of the issues at stake, or contestation at the national level. Third, the delegation relationship between the Commission and multiple principals is a repeated interaction. Accordingly, if agents slack, for example by exploiting the discretion given to them in a way undesired by principals, it is more likely to lead to loss of trust and eventually to strengthen control mechanisms in future interactions. This relationship of mutual trust can be disrupted if principals are dissatisfied with the agent's performance. More systematic studies are needed that analyse principal-agent relationships over time.

Acknowledgements This project received generous funding from the European Union's Seventh Framework Programme for Research, Technological Development and Demonstration under ERC grant agreement no. 312368 and from the DFG Grant CO 850/5-1. Earlier versions of this article were presented at EUSA 2015 in Boston, at the workshop EU as Global Negotiator at the European University Institute 2014 in Florence, at the Minda de Gunzburg Center for European Studies at Harvard University in 2015. I am particularly grateful to the three anonymous reviewers for their constructive and extensive suggestions, which were of great help in improving the paper substantially. I would also like to thank Johan Adriaensen, Dirk de Bièvre, Tom Delreux, Markus Gastinger, Adrienne Héritier, Paulette Kurzer, Matthias Matthijs, Tony Müller, Sophie Meunier, Alasdair Young, and Henning Schmidtke for their valuable suggestions along the way.

Funding Open Access funding enabled and organized by Projekt DEAL.

Open Access This article is licensed under a Creative Commons Attribution 4.0 International License, which permits use, sharing, adaptation, distribution and reproduction in any medium or format, as long as you give appropriate credit to the original author(s) and the source, provide a link to the Creative Commons licence, and indicate if changes were made. The images or other third party material in this article are included in the article's Creative Commons licence, unless indicated otherwise in a credit line to the material. If material is not included in the article's Creative Commons licence and your intended use is not permitted by statutory regulation or exceeds the permitted use, you will need to obtain permission directly from the copyright holder. To view a copy of this licence, visit http://creativecommons.org/licen ses/by/4.0/.

\section{References}

Agence Europe. 2007. Seoul Makes Concessions Next Week to Spur Conclusion of FTA. Accessed 12 Oct 2007.

Agence Europe. 2009a. Commission Reservations over Free Trade Agreement. Accessed 28 July 2009. Agence Europe. 2009b. Still No Consensus Between Twenty-seven on FTA. Accessed 9 Mar 2009.

Agence Europe. 2010a. Parliamentary Committee Approves Safeguard Clause in Free Trade Agreement with South Korea. Accessed 23 June 2010.

Agence Europe. 2010b. Threat of Italian Veto to FTA with South Korea. Accessed 8 Sept 2010. Agence Europe. 2012. Free Trade Negotiations Finalised. Accessed 17 Dec 2012.

Bazerman, Max H. 1999. Rational Authority Allocation to an Agent. In Negotiating on Behalf of Others, ed. Robert H. Mnookin and Lawrence Susskind, 81-85. Thousand Oaks: Sage Publications. 
Billiet, Stijn. 2006. From GATT to the WTO: The Internal Struggle for External Competences in the EU. Journal of Common Market Studies 44(5): 899-919.

Committee on International Trade: European Parliament. 2010. Draft Recommendation on the Proposal for a Council Decision Concluding the Free Trade Agreement between the European Union and its Member States, of the one Part and the Republic of Korea, of the Other Part Brussels: European Parliament.

Coremans, Evelyn, and Bart Kerremans. 2017. Agents as Information Asymmetry Managers in EU Trade Policy-Making. In The Principal Agent Model and the European Union, ed. Tom Delreux and Johan Adriaensen, 227-253. Cham: Palgrave Macmillan.

Council of the European Union. 2014. Directives for the Negotiation on the Transatlantic Trade and Investment Partnership between the European Union and the United States of America. Brussels: Council of the European Union.

Cutcher-Gerschenfeld, Joel E., and Michael Watkins. 1999. Toward a Theory of Representation in Negotiation. In Negotiating on Behalf of Others, ed. Robert H. Mnookin and Lawrence Susskind, 23-51. Thousand Oaks: Sage Publications.

da Conceição-Heldt, Eugénia. 2010. Who Controls Whom? Dynamics of Power Delegation and Agency Losses in EU Trade Politics. JCMS: Journal of Common Market Studies 48(5): 1109-1126.

da Conceição-Heldt, Eugénia. 2011. Variation in EU Member States' Preferences and the Commission's Discretion in the Doha Round. Journal of European Public Policy 18(3): 402-418.

da Conceição-Heldt, Eugénia. 2013. Do Agents "Run Amok"? Agency Slack in the EU and US Trade Policy in the Doha Round. Journal of Comparative Policy Analysis 15(1): 21-36.

da Conceição-Heldt, Eugénia. 2014. When Speaking with a Single Voice Isn't Enough: Bargaining Power (A)symmetry and EU External Effectiveness in Global Trade Governance. Journal of European Public Policy 21(7): 980-995.

da Conceição-Heldt, Eugénia, and Sophie Meunier. 2014. Speaking with a Single Voice: Internal Cohesiveness and External Effectiveness of the EU in Global Governance. Journal of European Public Policy 21(7): 961-979.

De. Ville, F., and G. Siles-Brügge. 2016. TTIP: The Truth about the Transatlantic Trade and Investment Partnership. Chichester: Polity.

Delreux, Tom, and Johan Adriaensen, eds. 2017. The Principal-Agent Model and the European Union. Basingstoke: Palgrave Macmillan.

Directorate General for External Policies. 2009. The EU-Korea Free Trade Agreement. Edited by Policy Department. Brussels: European Parliament.

Directorate-General for External Policies Policy Department. 2014. In-Depth Analysis: Negotiations on the EU-Canada Comprehensive Economic and Trade Agreement (CETA) concluded. Brussels: European Parliament.

Dür, Andreas. 2008. Bringing Economic Interests Back into the Study of EU Trade Policy-Making. British Journal of Politics and International Relations 10(1): 27-45.

Dür, Andreas, and Dirk De Bièvre. 2007. Inclusion Without Influence? NGOs in European Trade Policy. Journal of Public Policy 27(1): 79-101.

Dür, Andreas, and Manfred Elsig. 2011. The EU's Foreign Economic Policies: A Principal-agent Perspective. Journal of European Public Policy 18(3): 323-461.

Dür, Andreas, and Hubert Zimmermann. 2007. Introduction: The EU in International Negotiations. Journal of Common Market Studies 45(4): 771-787.

Elsig, Manfred. 2013. The EU as an Effective Trade Power? Strategic Choice of Judicial Candidates in the Context of the World Trade Organization. International Relations 27(3): 325-340.

EurActiv. 2014. TTIP and the Arbitration Clause. EurActiv. http://www.euractiv.com/sections/ttip-andarbitration-clause. Last Modified 8-12 Dec 2014, Accessed 11 Dec 2015.

European Commission. 2015. Trade for All: Towards a More Responsible Trade and Investment Policy. Luxembourg: Publications Office of the European Union.

European Commission. 2019. Overview of FTA and Other Trade Negotiations. European Commission. https://trade.ec.europa.eu/doclib/docs/2006/december/tradoc_118238.pdf. Accessed 22 Dec.

European Commission. 2020. Negotiations and Agreements: Implementing EU Agreements. European Commission. https:/ec.europa.eu/trade/policy/countries-and-regions/negotiations-and-agreements/. Accessed Mar 17.

European Parliament. 2011a. Debates: EU-Canada Trade Relations. https://www.europarl.europa.eu/ doceo/document/CRE-7-2011-06-06-ITM-019_EN.html. Accessed 30 May 2021. 
European Parliament. 2011b. EU-South Korea Free Trade Agreement Passes Final Hurdle in Parliament. https://www.europarl.europa.eu/news/en/press-room/20110216IPR13769/eu-south-korea-free-tradeagreement-passes-final-hurdle-in-parliament. Accessed 30 May 2021.

European Parliament. 2014. Negotiations on the EU-Canada Comprehensive Economic and Trade Agreement (CETA) Concluded. Directorate-General for External Policies DG EXPO/BPolDep/ Note/2014_106.

European Parliament. 2015a. June Plenary: Postponement of TTIP Plenary Vote and Debate. https:// www.europarl.europa.eu/news/en/press-room/20150224BKG25024/the-european-parliament-andthe-ttip/4/june-plenary-postponement-of-ttip-plenary-vote-and-debate. Accessed 30 May 2021.

European Parliament. 2015b. Resolution Adopted on 8 July 2015 on the Negotiations for the Transatlantic Trade and Investment Partnership (TTIP). http://www.europarl.europa.eu/sides/getDoc.do? pubRef=-//EP//TEXT+TA+P8-TA-2015-0252+0+DOC+XML+V0//EN. Accessed 11 Dec 2015

European Parliament. 2019. Press Conference: David Martin (S\&D, Uk), Rapporteur, And Cecilia Malmstrom, Commissioner For Trade, On EU-Singapore Free Trade And Investment Protection Agreements. https://multimedia.europarl.europa.eu/en/press-conference-david-martin-s-d-uk-rapporteurand-cecilia-malmstrom-commissioner-for-trade-on-eu-s_20190213-1430-SPECIAL-PRESSER_vd. Accessed 30 May 2021.

European Parliament. 2021. Results of the 2019 European Elections. https://www.europarl.europa.eu/ election-results-2019/en. Accessed 30 May 2021.

Gilardi, Fabrizio. 2008. Delegation in the Regulatory State: Independent Agencies in Western Europe. Cheltenham: Edward Elgar.

Gstöhl, Sieglinde, and Dirk De Bièvre. 2017. The Trade Policy of the European Union. The European Union Series: Red Globe Press.

Hawkins, Darren G., David A. Lake, Daniel L. Nielson, and Michael J. Tierney. 2006. Delegation Under Anarchy: States, International Organizations, and Principal-Agent Theory. In Delegation and Agency in International Organizations, ed. Darren G. Hawkins, David A. Lake, Daniel L. Nielson, and Michael J. Tierney, 3-38. Cambridge: Cambridge University Press.

Heldt, Eugénia. 2017a. Multiple Principals' Preferences, Types of Control Mechanisms and Agent's Discretion in Trade Negotiations. In The Principal Agent Model and the European Union, ed. Tom Delreux and Johan Adriaensen, 203-226. Cham: Palgrave Macmillan.

Heldt, Eugénia. 2020. Contested EU Trade Governance: Transparency Conundrums in TTIP Negotiations. Comparative European Politics 18: 215-232.

Heldt, Eugénia. 2017b. Regaining Control of Errant Agents? Agency Slack at the European Commission and the World Health Organization. Cooperation and Conflict 52(4): 469-484.

Jančić, Davor. 2016. The Role of the European Parliament and the US Congress in Shaping Transatlantic Relations: TTIP, NSA Surveillance, and CIA Renditions. Journal of Common Market Studies 54(4): 896-912.

Kaufman, Gordon M. 1999. Minimizing Agency Costs: Toward a Testable Theory. In Negotiating on Behalf of Others, ed. H. Robert, 127-132. Mnookin and Lawrence Susskind. Thousand Oaks: Sage Publications.

Khorana, Sangeeta, and María García. 2018. Handbook on the EU and International Trade. Northampton, MA: Edward Elgar Publishing.

Larsén, Magdalena Frennhoff. 2020. Parliamentary Influence Ten Years after Lisbon: EU Trade Negotiations with Japan. Journal of Common Market Studies 58(6): 1540-1557.

Macaj, Gjovalin, and Kalypso Nicolaïdis. 2014. Beyond “one voice”? Global Europe's Engagement with its own Diversity. Journal of European Public Policy 21(7): 1067-1083.

Meunier, Sophie. 2000. What Single Voice? European Institutions and EU-U.S. Trade Negotiations. International Organization 54(1): 103-135.

Meunier, Sophie. 2014. Divide and Conquer? China and the Cacophony of Foreign Investment Rules in the EU. Journal of European Public Policy 21(7): 996-1016.

Meunier, Sophie, and Kalypso Nicolaidis. 1999. Who Speaks for Europe? The Delegation of Trade Authority in the European Union. Journal of Common Market Studies 37(3): 477-501.

Mnookin, Robert H., and Jonathan R. Cohen. 1999. Introduction. In Negotiating on Behalf of Others, ed. Robert H. Mnookin and Lawrence Susskind, 1-20. Thousand Oaks: Sage Publications.

Moschella, Manuela, and Lucia Quaglia. 2015. To Agree or Not to Agree? Explaining the Cohesiveness of the European Union in the Group of Twenty. Journal of European Public Policy 23(6): 906-927.

Nicolaidis, Kalypso. 1999. Minimizing Agency Costs in Two-Level Games: Lessons from the Trade Authority Controversies in the United States and the European Union. In Negotiating on Behalf 
of Others, ed. Robert H. Mnookin and Lawrence Susskind, 87-126. Thousand Oaks: Sage Publications.

Nielson, Daniel, and Michael Tierney. 2003. Delegation to International Organizations: Agency Theory and World Bank Environmental Reform. International Organization 57(2): 241-276.

Niemann, Arne, and Charlotte Bretherton. 2013. EU External Policy at the Crossroads: The Challenge of Actorness and Effectiveness. International Relations 27(3): 261-275.

Niemann, Arne, and Judith Huigens. 2011. The European Union's Role in the G8: A Principal-Agent Perspective. Journal of European Public Policy 18(3): 420-442.

Pollack, Mark A. 1997. Delegation, Agency, and Agenda Setting in the European Community. International Organization 51(1): 99-134.

Pollack, Mark A. 2003. The Engines of European Integration: Delegation, Agency, and Agenda Setting in the EU. Oxford: Oxford University Press.

Putnam, Robert D. 1988. Diplomacy and Domestic Politics: The Logic of Two-Level Games. International Organization 42(3): 427-460.

Rosén, Guri. 2017. The Impact of Norms on Political Decision-Making: How to Account for the European Parliament's Empowerment in EU external Trade Policy. Journal of European Public Policy 24(10): 1450-1470.

Rosén, Guri. 2015. Habit or Principle? Explaining the European Parliament's Increasing Powers in EU External Trade Policy. Olso: University of Oslo.

Schelling, Thomas. 1960. The Strategy of Conflict. Cambridge, MA: Harvard University Press.

Sebenius, James K. 1991. Negotiation Analysis. In International Negotiation. Analysis, Approaches, Issues, ed. Victor A. Kremenyuk, 203-215. San Francisco: Jossey-Bass Publishers.

Servent, Ariadna Ripoll. 2014. The Role of the European Parliament in International Negotiations after Lisbon. Journal of European Public Policy 21(4): 568-586.

Tallberg, Jonas. 2000. The Anatomy of Autonomy: An Institutional Account of Variation in Supranational Influence. Journal of Common Market Studies 38(5): 843-864.

Thatcher, Mark, and Alec Stone Sweet. 2002. Theory and Practice of Delegation to Non-Majoritarian Institutions. West European Politics 25(1): 1-22.

Thomas, Daniel C. 2012. Still Punching below its Weight? Coherence and Effectiveness in European Union Foreign Policy. Journal of Common Market Studies 50(3): 457-474.

Van den Hoven, Adrian. 2002. Interest Group Influence on Trade Policy in a Multilevel Polity: Analysing the EU Position at the Doha WTO Ministerial Conference. San Domenico di Fiesole: EUI.

Van-den-Putte, Lore, Ferdi De-Ville, and Jan Orbie. 2015. The European Parliament as an International Actor in Trade: From Power to Impact. In The European Parliament and Its International Relations, ed. Stelios Stavridis and Daniela Irrera, 52-69. Abingdon: Routledge.

Votewatch. 2015. Negotiations for the Transatlantic Trade and Investment Partnership (TTIP). http:// www.votewatch.eu/en/term8-negotiations-for-the-transatlantic-trade-and-investment-partnershipttip-motion-for-resolution-vote-.html\#/\#\#vote-tabs-list-2. Accessed 5 Nov 2015

Woll, Cornelia. 2006. The Road to External Representation: The European Commission's Activism in International Air Transport. Journal of European Public Policy 13(1): 52-69.

Young, Alasdair R. 2002. Extending European Co-operation: The European Union and the 'New' International Trade Agenda, European Policy Research Unit Series. New York: Manchester University Press.

Young, Alasdair R. 2012. Of Executive Preferences and Societal Constraints: Domestic Politics and Transatlantic GMO Dispute. Review of International Political Economy 18(4): 506-529.

Young, Alasdair R. 2017. European Trade Policy in Interesting Times. Journal of European Integration 39(7): 909-923.

Publisher's Note Springer Nature remains neutral with regard to jurisdictional claims in published maps and institutional affiliations.

Eugénia da Conceicao-Heldt holds the chair of European and Global Governance and is the founding dean of the School of Governance at the Technical University of Munich, Germany. 